THURSDAY, JUNE 26, 1873

\section{THE ENDOWMENT OF RESEARCH}

I.

THERE are not wanting signs that ere long the whole 1 question of the present condition of research in this country, and of its amelioration, will undergo a complete discussion. Those who are best acquainted with this condition, and the position occupied by England at the present moment in the Science of the world, will be the first to acknowledge the importance of general attention being directed to the subject.

When the matter comes to be considered by minds free from the trammels alike of tradition and of prejudice, it will doubtless be found strange that such a fundamental question should have waited so long before it should have asserted itself; on the other hand, it is perfectly clear that many who are even now considering it have utterly failed to grasp it as it will have to be grasped.

This lack of clearness in the appreciation of the vast bearings of the question is quite pardonable, and is, doubtless, to a large extent, the natural consequence of the manner in which physical science has been added on to the older knowledgc. It would seem, however, that a mere statement of a few fundamental positions should clear the view. These positions, most fortunately, arc rapidly asserting themselves.

First, we have the generally acknowledged fact that a nation's progress depends upon its Science. Science, in fact, is the engine which nust be as ever active in peace as the cannon's mouth is in war, and a nation may just as safely neglect one as the other.

This brings us to the second position. Does England as a nation pay as much heed to the onc as the other? or as much as other nations? To ask this question is to answer it. England as a nation does next to nothing for this peace armament, and on all hands it is acknowledged that the nation's progress from this point of view is in great danger, because the decline of research in England, not only relatively, but absolutcly, is so decided, that it is already a matter of history. We have long ago in these pages referred to Dr. Franlland's cvidence on this point; he is the acknowledged head of chemical science in this country and should surely know; and other men who cultivate other sciences have expressed the same opinions with regard to them.

To what then is this decline 10 be attributed? The reply to this question brings us to the third point, There is absolutely no career for the student of Science, as such, in this country. True scientific research is absolutely unencouraged and unpaid. The original investigator is of course the man here intended, not the man who turns Science into a means of livelihood, however honourable, either as a teacher or a manufacturer.

There can be no doubt that to this state of things our present condition is to be ascribed, and this point is, according to us, the key of the whole position. A glance at the condition of things in France and Germany will strengthen our view. Why was Germany till lately the acknowledged leader in all matters connected with the No. I91-VOL. vIII. advancement of knowledge? Because there were no such brilliant and highly paid careers open there as here to those who choose politics, the bench, the bar, or commerce, in preference to Scicnce. And what is happening there at present? a decline visible not alone to the far-sighted, because Germany is getting rich as England has long been rich. Why is France now endowing research on a large scale, and even proposing that the most successful students in her magnificent Polytechnic School should be allowed to advance Science as State servants? Because in France there is a government instructed enough to acknowledge that a decline of investigation may bring evil to the State, and that it is the duty of the State to guard against this condition of things at all cost, this condition till lately, there as here, being that outside of the State service, and outside of the professoriate, no means of existence are provided for a student of Science ; hence men of the most excellent promise are yearly lost to research, which undoubtedly also is the case with us.

What course then docs it behove us to pursue in this country, in order that Science may take up its true position in our midst?

Here again opinion is rapidly forming itself. It is obvious to all who have thought about the matter, that it is absolutcly indispensable that an employment, necessary for the public good, which is neglected to the State's detriment because in itself it does not bring in a livelihood, should be artificially supported, and artificially supported at the public expense. It would be quite justifiable, both from an economical and also a political point of view, to provide for the needs of knowledge out of the taxation of the country ; because the taxpayer gets back his quid pro quo for the taxes he pays in the form of the amelioration of the conditions of living, as he gets it back in the form of security and good government.

It will probably be a considerable time before this truth is brought home to the public mind so completely as to render possible any large grant of national income for this purpose; but there are not wanting indications that statesmen of all parties are awakening to its reality, which in point of fact has long been conceded in principle. Still, such a source of support for Science to any very large cxtent must appear, even to the most sanguine, a thing of the future.

The area of knowledge will probably, in the future, increase beyond the means of any artificial support less than the national one; but perhaps it cannot be said that this state of things exists at present.

What, then, are we to do in the mean time? Have we no means which are at hand and immediately availablc, which may suffice to support the present claims of knowledge, without drawing too extensively upon the long-suffering or the intelligence of the taxpayer?

IVc have the means, if we will only employ themnay more, some of them are now, for the most part, lying idle-of not only supplying all the needs of the physical and other sciences, but of supplying them magnificently. 'To mention no other sources of supply there is the Patent Fund, and the endowments of the colleges of the old Universities.

As to the Patent Fund, it is not too much to say that a 
large part has been derived from the application of the abstract truths of physical science to the requirements of ordinary life, and that therefore the needs of physical science would be properly provided for out of it.

As to the College Endowments, whichever way we look at them, either as privatc bequests, as they are at length ceasing to be regarded, or as public funds, the conclusion is the same : their proper destination is the support of learning and Science.

If we look upon them as private bequests, and interpret the wills of founders and benefactors on the usual çi-pris principle, we should be right in devoting to investigation of facts at first hand the funds which were left by the farsecing men of the time of the revival of letters for the support of book-learning, which at that time occupied the place of modern Science. That they so regarded the aim of these bequests is shown, amongst other things, very remarkably by the universal annexation to the enjoyment of them of the condition of residence within the Universitics. When the whole, or the major part, of the materials of investigation was enshrined in libraries, to insist that a man should remain where libraries were was to insist that he should remain in his workshop.

If on the other hand we are to regard these endowments as public funds, as is now generally agreed, is it right that such public funds should be consumed either in educating those who are practically as well able to pay for their own education as those who now reccive a similar one at, say London 'University, an institution which is not aided by the State; or in supplying a life-maintenance to a considerable body of able young men, in return for passing a good examination at the outset of life?

It is well known that the ordinary Fellow of a college does not dream for a moment that he has any dutics towards knowledge or Scicnce. He regards the public money which he enjoys as a portion in a frechold estate, to enable him to tide over the uncertain years which come at the commencement of the ordinary professional carcer, the brilliant rewards of which we have shown to be the great cause of the decline of Science in this country, because they enable the practical life to outbid in attractiveness the laborious but most necessary pursuit of truth.

\section{CHAUVEAU'S ANATOMY OF DOMESTI- CATED ANIMALS}

The Comparative Anatomy of the Domesticated Animals. By A. Chatuveau. Translated and edited by G. Flemming, Vet.-Surg. R.E. (J. and A. Churchill.)

FOR a long time there has been a great want felt by I veterinary surgeons of a first-class work on the anatomy of the horse and other domestic animals, to be to them as valuable and trustworthy a book of reference as Quain and Sharpey's Anatomy is to the student of human anatomy. This feeling has induced Mr. Flemming to undertake the very arduous and considerable task of translating from the French the generally esteemed "Traité d'Anatomie Comparée des animaux domestiques" of MI. Chauvcau. The high position held by the Veterinary School of Lyons, and the great scientific reputation of its Professor, are sufficient guarantee for the cxcellence and accuracy of the original work before us, so that it will be unnecessary to enter into a detailed criticism of it: it will therefore be our chief duty to consider the manner in which the translation has been performed.

There are, however, one or two points to which we should like to draw attention in the work itself. First respecting the nomenclature of the lobes of the liver in the horse, Prof. Chauveau, as do most of the authors on the same subject, incorrectly calls the Caudate lobe the Spigelian. This error was clearly pointed out by Prof. Flower in his Hunterian Lectures last year, when he conclusively proved that the free, ear-shaped lobe, which is situated to the right of the vena porta in the horse, rhinoceros and tapir, is the caudate and not the spigelian lobe. This last is represented by a long attached transverse ridge of hepatic tissue, situated further to the left. Again, it is not clear why the protometra is said to be incorrectly termed the uterus mascululinus, for it is certainly not a gland in the ordinary sense of the word, and is as certainly the rudiment of the duct which developes into the uterus in the female. In the paragraph on the small horny plates, called "chesnuts," found on the lower third of the inner face of the forearm and at the upper extremity of the inner face of the metatarsal hone of the horse, the author remarks that "In solipeds, the chesnut is the representative of the thumb." That such is the case is, to say the least, extremely doubtl ul particularly in any member of the class Ungulata; anu from the fact that in the rhinoceros and tapir the second digit is perfectly developed, these epidermic appendages would be most probably larger in them than in Horse, if they represented the pollex and hallux; however they are altogether absent. That these horny plates in the fore-limb are situated above the carpus, is likewise not in harmony with their representing the thumbs.

Respecting the translation, which considering the size of the volume, must have been a very serious undertaking, the reader will, in the majority of cases, learn as correctly and as easily as from the original French. A perusal of several portions of the work seems to indicate that the translation has been performed by more than a single hand, for in some portions it is not so good as in others, and different words are cmployed to $\mathrm{ex}$ press the same one in the original. If there is any fault to find, it is one which may be considered by some to be rather an advantage than not, namely, that the rendering is too literal. A verbatim translation is in some cases not capable of giving the full force of the author's meaning in scientific as well as in other subjects, cach language having an idiomatic phraseology of its own. For instance, the 'middle of the diaphragm may be correctly termed in French "le centre phrénique," but it is more than perplexing to comprehend at first sight what is meant by "the phrenic centre." The cavities of the heart (les pockes) are not called "pouches" by English anatomists, and the colon is succulated (bosselé), not "bosselated;" this latter word is not to be found in some, periaps not in any standard dictionaries. The stylo-glossus muscle does not "respond" (il repond) but corresponds "with the mylo-hyoid outwardly and the genio-glossus inwardly." The large colon of the horse is said to be fixed by adherence to the "cross of the crecum;" we do not know what the cross of the crecum is, 